\title{
Information technology for the implementation of case-law management of end-to-end business processes
}

\section{Serhii Chalyi ${ }^{1}$ \\ Levykin Ihor ${ }^{2}$}

${ }^{1}$ Kharkiv National University of Radio Electronics, 14 Nauky Ave, KharkivUA-61166,Ukraine, serhii.chalyi@nure.ua

${ }^{2}$ Kharkiv National University of Radio Electronics, 14 Nauky Ave, KharkivUA-61166, Ukraine, ihor.levykin@nure.ua

distribute resources between them based on formalized experience, presented in the form of precedents.

The main problem of the operational management of endto-end business processes competing for common resources is the timely development of their mathematical models.

\section{PROBLEM SOLUTION AND RESULTS}

The solution to this problem is primarily associated with the presence of input and output data of the process, taking into account the influence of disturbances and the choice of control actions to achieve the desired result [1.2]. Therefore, it is proposed to use precedent models of analogues of such processes with their subsequent adjustment to the parameters of the models of controlled end-to-end business processes. This process is implemented using Process Mining technology [3].

To complete the stages of this technology, a generalized information technology of case-based management of end-toend business processes is proposed, presented in the form of the following sequence of actions:

- Simplification of case models of end-to-end business processes, taking into account their current state;

- Estimation of the lead time of the end-to-end business process according to its current state;

- Adaptation of models of the set of processes performed;

- Integration of end-to-end business process models for a new order;

- Management of ongoing and incoming new orders.

Implementation of the action <Simplification of case models of end-to-end business processes taking into account their current state $>$ is carried out taking into account one of its three states regarding the delay in their execution. The first condition of the PSU is characterized by the impossibility of its use in subsequent execution; the second state ensures the achievement of the target state with delays in the execution of the business process and the third state ensures the achievement of the target state without delay intervals. The simplification of the case model is supported by the appropriate method, which allows removing from the model those traces of the solution of the problem that do not further include the processing of objects by the name and values of their properties [4]. Метод включает в себя следующие этапы. 1. Формирование ограничений на новый бизнес-процесс. 2. Корректировка лога текущего бизнес-процесса. 3. Корректировка модели бизнес-процесса методами Process Mining. 4. Удаление интервалов выполнения действий и ожидания, не соответствующие полученной на этапе 3 модели.

The input for this action is: an event log that records all the actions in the corresponding database formed by the information system. Such databases contain information about 
the precedent model of analogues and properties of objects (products, services). The procedure for obtaining the model of the current precedent, the formation, selection and adjustment of the analogue precedent model, carried out using the methods of the Process Mining technology [5].

After the step of obtaining a simplified precedent model of the analogue, carried out at the first stage of this technology, the process proceeds to the action $<$ Estimation of the time to complete a business process by its current state $>$. The input of this action is a simplified precedent model of a business process and data on the duration of the intervals of waiting for its access to shared resources and runtime.

The execution of the $<$ Estimation of the business process execution time by its current state $>$ is carried out taking into account temporal restrictions imposed on the process. In this case, a subset of the possible trajectories of achieving the final state of the process of solving the problem of analyzing the data of both the event log and the model at the current time is determined. The duration of the execution is determined by the sum of the waiting interval and the execution time of the action for each trajectory of the process.

The implementation of this action is supported by the method of checking the implementation of temporal constraints, which includes the following steps. 1 . The definition of a subset of the possible paths to achieve the final state of the business process. 2. Determining the time to reach the final state of the process relative to its current state for each trajectory of its execution. 3 . The selection of a subset of options for solving problems for which the completion time of the business process does not exceed a predetermined threshold level. 4. Determination of the total duration of waiting intervals for each of the possible trajectories of the business process.

After receiving such an assessment, the transition to the action <Adaptation of models across the entire set of processes $>$ is carried out. When this action is performed, by analogy with the first action, the current interval model of the set of processes is simplified (adapted) [6]. Those traces that will no longer be executed based on the previously selected trajectory determined during the execution of a particular process, taking into account the existing minimum and maximum intervals of the process, are deleted. The input of this action is the estimation of the process execution time by the current state and a database containing information on time intervals for all business processes that are performed. The result of this action is an adaptive interval model of a set of business processes.

Upon completion of the adaptation of models, the transition to the action $<$ Integration of business process models for a new order $>$ is performed.

The input for this action is: databases of orders, intervals of waiting for resources (equipment, technologies, personnel, materials, intervals of waiting for resources) and adaptive models of the set of processes being performed. The action is performed taking into account temporal constraints and the integration of models of a set of processes.

The result of this action is the refinement of the execution time of the new process by the waiting time of released resources with the calculation of the necessary time for its implementation and verification of the temporal restrictions imposed on it. The duration of the waiting interval is determined by the difference between the moment of generating a request for a resource for a new process and the moment they are released by executed processes. 5 After completing the previous action, the transition to the action $<$ Management of executed and incoming orders $>$ is performed.

The implementation of this action is carried out taking into account the assessment of the feasibility of the process and the imposed temporal restrictions. The way out are actions to manage ongoing and new orders.

This information technology supports the process of finding the necessary solution in the form of a sequence of priorities for the access of end-to-end business processes / orders to shared resources at all competitive points. The advantage of the technology is such an implementation of the process of finding the optimal sequences using the criteria of the remaining time and delay time for each business process, which ensures their implementation in a timely manner.

Its practical implementation is shown by the example of management of ongoing and incoming new orders. The process of finding the required solution consists in determining the optimal access orders to the common resources of 3 orders $(Z)$ at 7 competitive points (CT), which is shown in Fig. 1.

This example shows all the possible and optimal sequences of the passage of orders at all competitive points.

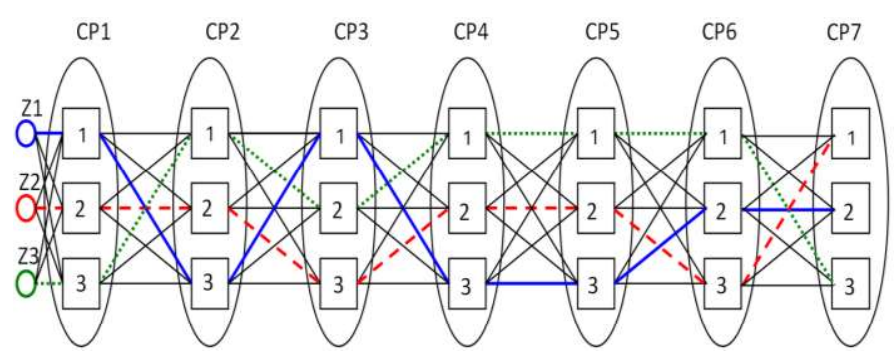

Figure 1. Sequences of orders of passage of orders of 7 competitive points

\section{CONCLUSIONS}

The proposed information technology for the process management of end-to-end business processes allows for the operational management of such processes based on the use of formalized analogue models. Their application ensures the implementation of many processes in accordance with the temporal restrictions imposed on them.

\section{REFERENCES}

[1] Vom Brocke, J. (2015). Handbook on Business Process Management 1. Introduction, Methods, and Information Systems. Springer-Verlag Berlin Heidelberg, P. 709.

[2] W.M.P. van der Aalst. (2013). Business Process Management: A Comprehensive Survey. ISRN Software Engineering, 1-37..

[3] [3] Chalyi S.F. Razrabotka obobshchennoi protsessnoi modeli pretsedenta, metoda ego formirovaniya i ispol'zovaniya./ S.F. Chalyi, I. V. Levykin // zhurnal «Upravlyayushchie sistemy i mashinY». - USIM, 2016. № 3. Mezhdunarodnyi nauchno-uchebnyi tsentr informatsionnykh tekhnologii i sistem NAN i MON Ukrainy m. Kiev - pp. 23-28,

[4] [4] Chalii, S.F. Metod adaptivnogo protsesnogo upravlinnya na osnovi pretsedentnogo pidkhodu / S.F. Chalii, I.V. Levikin // Nauko€mni tekhnologiii. - 2016. - № 4. - pp. 410-414.

[5] [5] Levykin, I.V. Metod sinteza tekhnologii process mining i sredstv imitatsionnogo modelirovaniya / I.V. Levykin // Tekhnologiya i tekhnika drukarstva KPI. - Kiev, 2016. - № 2 (52). - pp. 73-80.

[6] Chalyi S.F. Identification of the standby intervals in the business processes based on analysis of the sequence of events / S.F. Chalii, I.V. Levikin // Technology audit and production reserves. - 2016. - Vol. 5, N 2(31). - pp. 71-76. 